\title{
A STUDY ON MALAYSIAN ENGLISH LANGUAGE TEACHERS' READING HABITS: TYPES OF MATERIALS READ AND RATE OF EXTENSIVE READING
}

\author{
Sharmila a/p Appa Rwoo ${ }^{1}$, Chew Fong Peng ${ }^{2}$, Huzaina Abdul Halim ${ }^{3}$
}

1 Faculty of Education, University Malaya (UM), Malaysia Email: shar_rao83@outlook.com

2 Faculty of Education, University Malaya (UM), Malaysia

Email: fpchew@um.edu.my

Faculty of Education, University Malaya (UM), Malaysia

Email: huzaina@um.edu.my

\section{Article Info:}

\section{Article history:}

Received date: 13.12 .2019

Revised date: 29.12 .2019

Accepted date: 17.04.2020

Published date: 10.06 .2020

\section{To cite this document:}

Appa Rwoo, S., Chew, F. P., \& Halim, H, A. (2020). A Study on Malaysian English Language Teachers' Reading Habits: Types of Materials Read and Rate of Extensive Reading. International Journal of Humanities, Philosophy and Language, 3 (10), 18-34.

DOI: $10.35631 /$ IJHPL.310003.

\begin{abstract}
:
This study is carried out with the purpose of gaining more in-depth information in regard to the reading habits of 210 English Language (EL) teachers in the district of Klang, Selangor. A convenient sampling method is used to choose the respondents while data are gathered with a survey questionnaire. The first aim of this study is to study the types of materials read by ESL teachers. Secondly, it aims to identify the rate of extensive reading among these teachers. The results show that ESL teachers read mostly light reading materials online and shun heavy materials. The researcher also discovered that the rates of extensive reading among ESL teachers are average to high. Therefore, the Ministry of Education could implement nationwide reading programmes and teachers should take the initiative to read more.
\end{abstract}

Keywords:

English Language (EL) Teachers, Reading Habit, Extensive Reading

\section{Introduction}

English Language (EL) teachers' reading habits play a major role in determining their effectiveness, not only in teaching the target language, but also in promoting a reading habit among language learners. Applegate \& Applegate (2004) and Giles \& Tunks (2019) explain that teachers who are passionate readers are more likely to use positive teaching practices which engage and excite their learners. 
In Malaysia, EL teachers' reading habits is not a well-researched topic. The few studies available (Daik, 2006; Tharumaraj \& Noordin, 2011) have demonstrated that Malaysian EL teachers are not enthusiastic or extensive readers.

In line with this, this research tries to shed more light on the reading habits of EL teachers, mainly on the types of materials read by and rate of extensive reading among them.

This research aims to achieve these following objectives.

a) To determine the types of English reading materials read by EL teachers

b) To determine the rate of extensive reading among EL teachers.

This research answers these following research questions.

a) What are the types of English reading materials read by Malaysian EL teachers?

b) What is the rate of extensive reading among Malaysian EL teachers?

As one of the objectives of this research is to determine the rate of extensive reading among EL teachers, it is crucial to define extensive readers. According to the Longman Dictionary of Language Teaching \& Applied Linguistics (2002), 'extensive reading' is defined as "reading in quantity and in order to gain a general understanding of what is read" (p.193).

It is further explained that 'extensive reading' functions as a means to "develop good reading habits" by enhancing one's range of vocabulary and structure while promoting a love for reading.

\section{Literature Review}

\section{Principles Of Extensive Reading}

Day and Bamford (2002) describe extensive reading as a skill which follows these ten principles.

\section{The Material's Level Of Difficulty}

Reading a text which is beyond the readers' language competence not only discourages the readers from reading but also disrupts the smooth flow of understanding that is crucial for extensive reading. It should be noted that extensive reading is independent; free from the teachers' guidance and instructions. Therefore, the material read has to be within the readers' linguistic competence or the purpose of the activity will be lost. Studies have specified that, for an uninterrupted reading session, readers should be familiar with $98 \%$ of the words in the texts read. If readers are confronted with more than one unfamiliar word in every ten words, the effort will prove to be futile and stuttered (Day \& Bamford, 2002; The Extensive Reading Foundation, 2011).

\section{The Abundance Of Material Of Wide-Ranging Topics}

In relation to this principle, readers' level of interest is very influential in determining the success of extensive reading. In extensive reading, the readers' interest will only be sustained if the material provided is of the topic of their choice. Many reading activities in language classrooms are carried out with every student being given the same text and the assumption that they all have a high degree of interest towards the text. Unlike intensive reading, extensive reading only functions when readers are supplied with plenty of material of various topics so that they are able to read for multiple purposes (Day \& Bamford, 2002; The Extensive Reading Foundation, 2011). 


\section{The Material Must Be Of Readers' Choice}

In a similar vein, a connection between the second and third principle can be seen in the aspect of readers' interest. Extensive reading allows readers to discontinue reading any material which does not gain their interest. This gives the readers the choice to choose their own reading material and, in that process, push them to be more independent and responsible towards their own learning (Day \& Bamford, 2002; The Extensive Reading Foundation, 2011).

\section{Limitless Reading}

When all the three above-mentioned principles are fulfilled, it brings forth the fourth one; the extensiveness of the reading practice. The word 'extensive' itself is defined as "large in amount or scale" (English Oxford Living Dictionary, 2017) with extensive reading may be described as constant voluntary reading. Consequently, readers are not set with limits on how much they should read and "the amount of time spent actually reading" (Day \& Bamford, 2002). While a minimum limit could be set, readers should be encouraged to read as much as they can.

\section{The Purpose Of Reading}

What differentiates extensive reading from intensive reading is that the former is an endeavour of self-enjoyment and voluntary search for information while the latter is targeted for academic objectives. The requirement for total understanding of the text is less, if not, emphasised in extensive reading as the purpose of reading is attaining personal satisfaction from doing something pleasurable out of one's own volition (Day \& Bamford, 2002; The Extensive Reading Foundation, 2011).

\section{The Incentive For Reading Is Reading Itself}

Book lovers or those who read for pleasure usually say there is no greater pleasure derived while reading than reading itself. The reading process alone, if all the afore-mentioned principles are followed, will be rewarding without the need for any other external incentives. Nevertheless, younger or beginner readers need to be helped in being aware of the rewarding experience. Hence, there are a few options which language teachers could use to promote an appreciation for the readers' self-satisfaction. Language teachers may encourage their students talk or write about any of the characters, write a review of the books or perhaps re-enact a favourite scene from the book (Day \& Bamford, 2002). These tasks will further enrich the readers' knowledge and interest further without appearing very rigorous and academic.

\section{Extensive Reading Is Reading Fast And Fluently}

Once the reading material meets the six criteria stated above, readers are able to read fluently. Extensive reading promotes learning approaches which encourage independence. As such, the use of dictionaries is discouraged so that the readers will focus on the "general meaning' of the text rather than looking up for the meaning of unfamiliar words. The speed of reading is essential in extensive reading because pausing or slowing down one's reading pace will kill the momentum built (Day \& Bamford, 2002; The Extensive Reading Foundation, 2011).

\section{Reading Is Silent And Individual}

In contrast to intensive reading, extensive reading makes way for personalised individual and silent reading. As it happens with intensive reading, extensive reading doesn't require the readers to read aloud or decipher the text together in a class. The resulting period of silence actually permits the readers to build their own understanding of the text and "discovers how foreign language reading fits into their lives" (Day \& Bamford, 2002). 


\section{Teachers As Guides And Facilitator}

Although extensive reading stresses heavily on promoting readers' independence, there is still the need for teachers to be around as a guide and to facilitate the readers' transition throughout the reading process. In some cases, students who are trained to read intensively academic and linguistically difficult material feel unsure of what to do when given the independence to read anything interesting and within their linguistic capability. Thus, it falls upon their teachers to initiate an extensive reading session by explaining its benefits and helping students to choose enjoyable reading material which can be understood easily. Here, teachers play the multiple roles of facilitator, consultant, motivator and guide (Day \& Bamford, 2002; The Extensive Reading Foundation, 2011).

\section{Teachers As Role Models}

The final principle of extensive reading revolves around the influence teachers have on their charges' reading habits. It goes without saying that, in order to promote interest towards reading among their students, the teachers themselves would have to project a positive image. Teachers themselves should possess tremendous interest and passion by reading vociferously in the quest to promote extensive reading among their students. Reading teachers are also encouraged to set up book discussions in class in which teachers and students discuss or analyse the books read by the students. In conclusion, it is a must for language teachers to be extensive readers as well (Day \& Bamford, 2002; The Extensive Reading Foundation, 2011).

To conclude, the above-mentioned principles are useful to be referred to by language teachers when determining the ways extensive reading should be carried out in their classrooms.

\section{Extensive Reading Among EL Teachers}

There is a growing concern about aliteracy among teachers (Giles \& Tunk, 2019), with EL teachers displaying a lack of interest towards reading a wide range of materials. The lack of a strong reading habit is also prevalent among Malaysian EL teachers as proven by Daik (2006) and Tharumaraj and Noordin (2011). Daik (2006), in his study on secondary school ESL teachers' reading habits, proved that while most of the 118 ESL teachers studied did read academic and non-academic material, most of them spent only a few hours a week to read. He further concluded that most of his respondents have poor reading habits.

In a similar vein, Tharumaraj and Noordin (2011), in their study on ESL teachers' reading habits and the strategies used in the teaching of reading skills, concluded that $60 \%$ of the respondents partook in leisure reading "almost every day or every other day" but they read mostly newspapers and magazines.

The above-mentioned studies have demonstrated the fact that Malaysian EL teachers do not read extensively, and their reading choices are limited to light materials.

English Language teachers in other South East Asian nations such as Singapore are also deemed to have weak reading habits (Kwek, Albright \& Kramer-Dahl, 2007). In spite of acknowledging the importance of reading for the own benefit, Singaporean English Language teachers choose their reading materials for "functional purposes rather than recreational purposes" (Kwek, Albright \& Kramer-Dahl, 2007; p.76). In their paper, Kwek, Albright \& Kramer-Dahl (2007) further assert that the lack of reading habits among Singapore's teachers. 
A study on 92 Turkish teachers revealed that while $65 \%$ of them thought of themselves as regular readers, only $2 \%$ of these teachers spend 2 hours daily to read Furthermore, just $30 \%$ read more than 21 books in a year or 2 books in month on average

(Aç kay, 2017).

Studies conducted among American teachers have demonstrated both positive and negative results. In her doctoral thesis, Donaldson (2016) scrutinizes the "reading histories and habits" of 158 Texan English language teachers and further affirmed the fact that these English teachers think of themselves as readers, find reading a pleasurable activity and love discussing about their reading experience.

On the other hand, Burgess, Sargent, Smith, Hill \& Morrison (2011) concluded that American teachers are not spending adequate time for recreational reading, with more than a fifth of the respondents not reading at least 1 book per month. Similarly, McKool and Gespass (2009) also discovered that more than $63 \%$ of the teachers they studied do not partake in recreational reading at all. Several other studies have further concurred that there is a worrying level of aliteracy among American in-service teachers (Nathanson, Pruslow and Levitt, 2008; Giles and Tunks, 2019).

All these studies illustrate the fact that the lack of strong reading habits among EL language teachers is a matter of grave concern. Therefore, it is imperative for the reasons causing this conundrum to be identified so that effective steps can be taken to solve it.

\section{Research Design And Methodology}

The design of this research, in line with the research problems, calls for the usage of survey methods. This is a descriptive study where the sample is selected based on the convenience sampling method. The sample surveyed consists of 210 EL teachers teaching in 15 public secondary schools in West Malaysia. The schools are located in urban and suburban areas. 182 $(86.7 \%)$ respondents are female while only $28(13.3 \%)$ are male.

The instrument used in this research is a questionnaire, which is designed based on questionnaires used in two previous studies; Pandian (1997) as well as Tharumaraj and Noordin (2011). There are several modifications made during the adaptation of these questionnaires to fit the objectives of this research.

The first modification is made to the types of reading materials. As Pandian's study was carried out before the advent of social media, the list of reading materials does not include online materials such as social media posts or e-books. Furthermore, the subject of Pandian's study was university undergraduates who might have had different reading preferences and priorities. Therefore, the questionnaire items had to be adapted to suit the preferences of EL teachers.

The second questionnaire adapted here is by Tharumaraj \& Noordin (2011), which was administered to EL teachers to investigate their reading habits and types of reading strategies they use when teaching English. As only the first half of the questionnaire is relevant to this research, the items in that section are used as guidance to design this questionnaire. In addition, the questionnaire by Tharumaraj \& Noordin includes only one online reading material; 'internet/websites'. Therefore, for this study, more online items are included in the list of reading materials read such as social media posts, blogs and e-books. Finally, items in Tharumaraj and Noordin's questionnaire which are related to ESL teachers' levels of reading engagement are also modified to make them more specific. 
This study's questionnaire contains 6 items about the respondents' demography and 40 items, with Likert-scale measurement, related to their reading habits. Items 7 until 12 enquire about the respondents' choice of reading materials and frequency read whereas items $13-40$ are related to their attitude towards reading.

A pilot study has been carried out among $30 \mathrm{EL}$ teachers in schools to evaluate the reliability of the instrument. The Cronbach alpha value of the instrument was at 0.781 , indicated that the questionnaire is reliable and can be used in the real study.

\section{Findings}

The demography of the respondents is illustrated in Table 1 .

Table 1: Respondents' Demography

\begin{tabular}{|c|c|c|c|}
\hline Free Variables & Category & $\begin{array}{l}\text { Frequency } \\
\text { (Total) }\end{array}$ & $\begin{array}{c}\text { Percentage } \\
(\%)\end{array}$ \\
\hline \multirow{3}{*}{ Age } & $25-30$ years old & 21 & 10.0 \\
\hline & $31-40$ years old & 105 & 50.0 \\
\hline & $41-50$ years old & 49 & 23.3 \\
\hline \multirow{4}{*}{ Gender } & $51-60$ years old & 35 & 16.7 \\
\hline & Male & 28 & 13.3 \\
\hline & Female & 182 & 86.7 \\
\hline & Diploma in Education (TESL) & 28 & 13.3 \\
\hline \multirow{6}{*}{$\begin{array}{l}\text { Highest } \\
\text { Professional } \\
\text { Qualification }\end{array}$} & Bachelor of Education (TESL) & 140 & 66.7 \\
\hline & $\begin{array}{l}\text { Bachelor of English Language and } \\
\text { Linguistics }\end{array}$ & 7 & 3.3 \\
\hline & Masters of Education (TESL) & 14 & 6.7 \\
\hline & Masters in Arts (Linguistics) & 7 & 3.3 \\
\hline & Masters of English Language Studies & 0 & 0.0 \\
\hline & Others & 14 & 6.7 \\
\hline \multirow{4}{*}{$\begin{array}{l}\text { English Language } \\
\text { Teaching } \\
\text { Experience }\end{array}$} & Less than 5 years & 35 & 16.6 \\
\hline & $5-10$ years & 65 & 31.0 \\
\hline & $11-20$ years & 35 & 16.7 \\
\hline & More than 20 years & 75 & 35.7 \\
\hline \multirow{7}{*}{$\begin{array}{l}\text { Cambridge } \\
\text { Placement } \\
\text { Result }\end{array}$} & A1 & 7 & 3.3 \\
\hline & A2 & 7 & 3.3 \\
\hline & B1 & 7 & 3.3 \\
\hline & B2 & 28 & 13.3 \\
\hline & $\mathrm{C} 1$ & 77 & 36.7 \\
\hline & $\mathrm{C} 2$ & 35 & 16.7 \\
\hline & Not Available & 49 & 23.3 \\
\hline \multirow{3}{*}{ School Category } & Urban & 21 & 10.0 \\
\hline & Suburban & 189 & 90.0 \\
\hline & Rural & 0 & 0.0 \\
\hline
\end{tabular}

Analysis of the respondents' demography shows that the respondents who are between the ages of 31- and 40-years old form the biggest percentage at 50\%. The majority of the respondents are female at $86.7 \%$ (182). Next, respondents with a Bachelor of Education (TESL) qualification form the biggest group $(140,66.7 \%)$. Meanwhile, teachers who have been teaching for more than 20 years form the majority of the respondents $(75,35.7 \%)$.

Copyright (C) GLOBAL ACADEMIC EXCELLENCE (M) SDN BHD - All rights reserved 
Next, more than a third of the respondents have scored a $\mathrm{C} 1$ for the Cambridge Placement Test $(77,36.7 \%)$ which was carried out in 2012. It is also observed that $90 \%$ of them are teaching in suburban schools.

In this research, descriptive analysis is used in order to analyse data which involve the values of mean, standard deviation, percentage and frequency of response to the questionnaire items. After the data is processed, the findings exhibit values which will be categorised according to the five categories outlined by the Educational Planning and Research Division of Malaysian Ministry of Education (2006). The objective of this endeavour is to illustrate the level and interpretation of the average mean scores as seen in Table 2.

Table 2: Average Score and Mean Interpretation

\begin{tabular}{ll}
\hline Average Mean Score & Interpretation \\
\hline $1.00-1.89$ & Very low \\
$1.90-2.69$ & Low \\
$2.70-3.49$ & Average \\
$3.50-4.29$ & High \\
$4.30-5.00$ & Very high \\
\hline
\end{tabular}

Research Question 1: What are the types of reading materials read most frequently by EL teachers?

Data presentation is continued with the distribution of the responses for Section B. The first part of this section is related to respondents' preferences of reading material and the frequency of these materials being read.

Table 3: ESL Teachers' Choice of English Reading Material (In a Week)

ESL TEACHERS’ CHOICE OF ENGLISH READING MATERIAL (IN A WEEK)

\begin{tabular}{|c|c|c|c|c|c|c|c|c|}
\hline NUM & $\begin{array}{l}\text { READING } \\
\text { MATERIAL }\end{array}$ & NONE & 1 DAY & $\begin{array}{c}3 \\
\text { DAYS }\end{array}$ & $\begin{array}{c}5 \\
\text { DAYS }\end{array}$ & DAILY & $\mathbf{M}$ & SD \\
\hline 1 & Newspapers & $\begin{array}{c}56 \\
(26.7 \%)\end{array}$ & $\begin{array}{c}28 \\
(13.3 \%)\end{array}$ & $\begin{array}{c}35 \\
(16.7 \%)\end{array}$ & $\begin{array}{c}28 \\
(13.3 \%)\end{array}$ & $\begin{array}{c}63 \\
(30.0 \%)\end{array}$ & 3.07 & 1.59 \\
\hline 2 & Magazines & $\begin{array}{c}77 \\
(36.7 \%)\end{array}$ & $\begin{array}{c}63 \\
(30.0 \%)\end{array}$ & $\begin{array}{c}49 \\
(23.3 \%)\end{array}$ & $\begin{array}{c}21 \\
(10.0 \%)\end{array}$ & 0 & 2.07 & 1.00 \\
\hline 3 & Tabloids & $\begin{array}{c}112 \\
(53.3 \%)\end{array}$ & $\begin{array}{c}56 \\
(26.7 \%))\end{array}$ & $\begin{array}{c}21 \\
(10.0 \\
\%)\end{array}$ & $\begin{array}{c}7 \\
(3.3 \%))\end{array}$ & $\begin{array}{c}14 \\
(6.7 \%)\end{array}$ & 1.83 & 1.16 \\
\hline 4 & Novels & $\begin{array}{c}105 \\
(50.0 \%)\end{array}$ & $\begin{array}{c}42 \\
(20.0 \%)\end{array}$ & $\begin{array}{c}35 \\
(16.7 \%)\end{array}$ & $\begin{array}{c}14 \\
(6.7 \%)\end{array}$ & $\begin{array}{c}14 \\
(6.7 \%)\end{array}$ & 2.00 & 1.24 \\
\hline 5 & Short stories & $\begin{array}{c}84 \\
(40.0 \%)\end{array}$ & $\begin{array}{c}49 \\
(23.3 \%)\end{array}$ & $\begin{array}{c}28 \\
(13.3 \%)\end{array}$ & $\begin{array}{c}21 \\
(10.0 \%)\end{array}$ & $\begin{array}{c}28 \\
(13.3 \%)\end{array}$ & 2.33 & 1.43 \\
\hline 6 & $\begin{array}{l}\text { Non-fiction } \\
\text { books }\end{array}$ & $\begin{array}{c}105 \\
(50.0 \%)\end{array}$ & $\begin{array}{c}63 \\
(30.0 \%)\end{array}$ & $\begin{array}{c}28 \\
(13.3 \%)\end{array}$ & $\begin{array}{c}7 \\
(3.3 \%)\end{array}$ & $\begin{array}{c}7 \\
(3.3 \%)\end{array}$ & 1.80 & 1.02 \\
\hline 7 & Encyclopaedia & $\begin{array}{c}105 \\
(50.0 \%) \\
\end{array}$ & $\begin{array}{c}42 \\
(20.0 \%) \\
\end{array}$ & $\begin{array}{c}35 \\
(16.7 \%) \\
\end{array}$ & 0 & $\begin{array}{c}28 \\
(13.3 \%) \\
\end{array}$ & 2.07 & 1.37 \\
\hline
\end{tabular}




\begin{tabular}{|c|c|c|c|c|c|c|c|c|}
\hline 8 & Online blogs & $\begin{array}{c}28 \\
(13.3 \%)\end{array}$ & $\begin{array}{c}35 \\
(16.7 \%)\end{array}$ & $\begin{array}{c}42 \\
(20.0 \%)\end{array}$ & $\begin{array}{c}21 \\
(10.0 \%)\end{array}$ & $\begin{array}{c}84 \\
(40.0 \%)\end{array}$ & 3.47 & 1.48 \\
\hline 9 & $\begin{array}{l}\text { Social } \\
\text { posts }\end{array}$ & $\begin{array}{c}7 \\
(3.3 \%)\end{array}$ & $\begin{array}{c}28 \\
(13.3 \%)\end{array}$ & $\begin{array}{c}21 \\
(10.0 \%)\end{array}$ & $\begin{array}{c}7 \\
(3.3 \%)\end{array}$ & $\begin{array}{c}147 \\
(70.0 \%)\end{array}$ & 4.23 & 1.26 \\
\hline 10 & Websites & 0 & $\begin{array}{c}49 \\
(23.3 \%)\end{array}$ & $\begin{array}{c}28 \\
(13.3 \%)\end{array}$ & $\begin{array}{c}14 \\
(6.7 \%)\end{array}$ & $\begin{array}{c}119 \\
(56.7 \%)\end{array}$ & 3.97 & 1.28 \\
\hline 11 & E-Books & $\begin{array}{c}133 \\
(63.3 \%)\end{array}$ & $\begin{array}{c}28 \\
(13.3 \%)\end{array}$ & $\begin{array}{c}14 \\
(6.7 \%)\end{array}$ & $\begin{array}{c}21 \\
(10.0 \%)\end{array}$ & $\begin{array}{c}14 \\
(6.7 \%)\end{array}$ & 1.83 & 1.30 \\
\hline 12 & Audio Books & $\begin{array}{c}168 \\
(80.0 \%)\end{array}$ & $\begin{array}{c}28 \\
(13.3 \%)\end{array}$ & 0 & $\begin{array}{c}7 \\
(3.3 \%)\end{array}$ & $\begin{array}{c}7 \\
(3.3 \%)\end{array}$ & 1.37 & 0.91 \\
\hline 13 & Comics & $\begin{array}{c}154 \\
(73.3 \%)\end{array}$ & $\begin{array}{c}21 \\
(10.0 \%)\end{array}$ & $\begin{array}{c}7 \\
(3.3 \%)\end{array}$ & $\begin{array}{c}21 \\
(10.0 \%)\end{array}$ & $\begin{array}{c}7 \\
(3.3 \%)\end{array}$ & 1.60 & 1.15 \\
\hline & Average & & & & & & 2.43 & 1.25 \\
\hline
\end{tabular}

If we look at the materials read more than 3 days a week, it can be seen that social media posts are the most widely read material $(175,83.3)$ by the respondents. This is followed by websites $(161,76.7)$ as the second-most read material among the respondents while at the third rank is blogs $(147,70.0)$. The least read material is audio book $(14,6.6)$.

The average mean score obtained is 2.43 (SD 1.25), which is interpreted as 'low' according to the scale in Table 2. Therefore, it can be concluded that ESL teachers surveyed are not reading as much and frequently as they should.

Research question 2: What are the rates of extensive reading among EL teachers?

Findings for the second research question are obtained by analysing the responses to the items related to positive reading habits in the questionnaire. Table 4 exhibits the data retrieved.

Table 4: Respondents' Responses to Items Related to Positive Reading Habits

\begin{tabular}{|c|c|c|c|c|c|c|c|c|c|}
\hline \multirow[t]{2}{*}{ Num } & \multirow{2}{*}{\multicolumn{2}{|c|}{ Item }} & \multirow{3}{*}{$\begin{array}{c}\text { SD } \\
0 \\
(0.0 \%)\end{array}$} & \multirow{3}{*}{$\begin{array}{c}\text { D } \\
56 \\
(26.7 \%)\end{array}$} & \multirow{3}{*}{$\begin{array}{c}\mathbf{N} \\
28 \\
(13.3 \%)\end{array}$} & \multirow{3}{*}{$\begin{array}{c}\mathbf{A} \\
84 \\
(40.0 \%)\end{array}$} & \multirow{3}{*}{$\begin{array}{c}\text { SA } \\
42 \\
(20.0 \%)\end{array}$} & \multirow{3}{*}{$\begin{array}{c}\mathbf{M} \\
3.53\end{array}$} & \multirow{3}{*}{$\begin{array}{c}\mathbf{D} \\
1.09\end{array}$} \\
\hline & & & & & & & & & \\
\hline 1 & $\begin{array}{l}\text { I read } \\
\text { materials } \\
\text { than one } \\
\text { day. }\end{array}$ & $\begin{array}{l}\text { English } \\
\text { for more } \\
\text { hour a }\end{array}$ & & & & & & & \\
\hline 2 & $\begin{array}{l}\text { I read } \\
\text { materials } \\
\text { having } \\
\text { alone. }\end{array}$ & $\begin{array}{r}\text { English } \\
\text { when } \\
\text { meals }\end{array}$ & $\begin{array}{c}28 \\
(13.3 \%)\end{array}$ & $\begin{array}{c}42 \\
(20.0 \%)\end{array}$ & $\begin{array}{c}42 \\
(20.0 \%)\end{array}$ & $\begin{array}{c}77 \\
(36.7 \%)\end{array}$ & $\begin{array}{c}21 \\
(10.0 \%)\end{array}$ & 3.10 & 1.22 \\
\hline 3 & $\begin{array}{l}\text { I read } \\
\text { materials } \\
\text { waiting. }\end{array}$ & $\begin{array}{l}\text { English } \\
\text { while }\end{array}$ & $\begin{array}{c}0 \\
(0.0 \%)\end{array}$ & $\begin{array}{c}21 \\
(10.0 \%)\end{array}$ & $\begin{array}{c}42 \\
(20.0 \%)\end{array}$ & $\begin{array}{c}112 \\
(53.3 \%)\end{array}$ & $\begin{array}{c}35 \\
(16.7 \%)\end{array}$ & 3.77 & 0.85 \\
\hline 4 & $\begin{array}{l}\text { I read } \\
\text { materials } \\
\text { travelling. }\end{array}$ & $\begin{array}{c}\text { English } \\
\text { when }\end{array}$ & $\begin{array}{c}28 \\
(13.3 \%)\end{array}$ & $\begin{array}{c}42 \\
(20.0 \%)\end{array}$ & $\begin{array}{c}42 \\
(20.0 \%)\end{array}$ & $\begin{array}{c}91 \\
(43.3 \%)\end{array}$ & $\begin{array}{c}14 \\
(6.7 \%)\end{array}$ & 3.17 & 1.13 \\
\hline
\end{tabular}




\begin{tabular}{|c|c|c|c|c|c|c|c|c|}
\hline 5 & $\begin{array}{l}\text { I read English } \\
\text { materials before } \\
\text { going to bed. }\end{array}$ & $\begin{array}{c}7 \\
(3.3 \%)\end{array}$ & $\begin{array}{c}42 \\
(20.0 \%)\end{array}$ & $\begin{array}{c}42 \\
(20.0 \%)\end{array}$ & $\begin{array}{c}77 \\
(36.7 \%)\end{array}$ & $\begin{array}{c}42 \\
(20.0 \%)\end{array}$ & 3.50 & 1.12 \\
\hline 6 & $\begin{array}{l}\text { I go to the library } \\
\text { to read and borrow } \\
\text { books every week. }\end{array}$ & $\begin{array}{c}56 \\
(26.7 \%)\end{array}$ & $\begin{array}{c}112 \\
(53.3 \%)\end{array}$ & $\begin{array}{c}35 \\
(16.7 \%)\end{array}$ & $\begin{array}{c}7 \\
(3.3 \%)\end{array}$ & $\begin{array}{c}0 \\
(0.0 \%)\end{array}$ & 1.97 & 0.75 \\
\hline 7 & $\begin{array}{l}\text { I subscribe to } \\
\text { English language } \\
\text { magazines. }\end{array}$ & $\begin{array}{c}42 \\
(20.0 \%)\end{array}$ & $\begin{array}{c}91 \\
(43.3 \%)\end{array}$ & $\begin{array}{c}35 \\
(16.7 \%)\end{array}$ & $\begin{array}{c}35 \\
(16.7 \%)\end{array}$ & $\begin{array}{c}7 \\
(3.3 \%)\end{array}$ & 2.40 & 1.09 \\
\hline 8 & $\begin{array}{l}\text { I always buy } \\
\text { English reading } \\
\text { materials from the } \\
\text { bookstores. }\end{array}$ & $\begin{array}{c}28 \\
(13.3 \%)\end{array}$ & $\begin{array}{c}42 \\
(20.0 \%)\end{array}$ & $\begin{array}{c}28 \\
(13.3 \%)\end{array}$ & $\begin{array}{c}63 \\
(30.0 \%)\end{array}$ & $\begin{array}{c}49 \\
(23.3 \%)\end{array}$ & 3.30 & 1.37 \\
\hline 9 & $\begin{array}{l}\text { I use my } \\
\text { smartphone to read } \\
\text { English materials } \\
\text { more than other } \\
\text { functions. }\end{array}$ & $\begin{array}{c}0 \\
(0.0 \%)\end{array}$ & $\begin{array}{c}0 \\
(0.0 \%)\end{array}$ & $\begin{array}{c}42 \\
(20.0 \%)\end{array}$ & $\begin{array}{c}84 \\
(40.0 \%)\end{array}$ & $\begin{array}{c}84 \\
(40.0 \%)\end{array}$ & 4.20 & 0.75 \\
\hline 10 & $\begin{array}{l}\text { I always buy } \\
\text { English reading } \\
\text { material online. }\end{array}$ & $\begin{array}{c}49 \\
(23.3 \%)\end{array}$ & $\begin{array}{c}84 \\
(40.0 \%)\end{array}$ & $\begin{array}{c}35 \\
(16.7 \%)\end{array}$ & $\begin{array}{c}28 \\
(13.3 \%)\end{array}$ & $\begin{array}{c}14 \\
(6.7 \%)\end{array}$ & 2.40 & 1.17 \\
\hline 11 & $\begin{array}{l}\text { I have more than } \\
50 \text { English reading } \\
\text { materials at home. }\end{array}$ & $\begin{array}{c}14 \\
(6.7 \%)\end{array}$ & $\begin{array}{c}21 \\
(10.0 \%)\end{array}$ & $\begin{array}{c}21 \\
(10.0 \%)\end{array}$ & $\begin{array}{c}70 \\
(33.3 \%)\end{array}$ & $\begin{array}{c}84 \\
(40.0 \%)\end{array}$ & 3.90 & 1.22 \\
\hline 12 & $\begin{array}{l}\text { I feel relaxed when } \\
\text { I read English } \\
\text { materials. }\end{array}$ & $\begin{array}{c}0 \\
(0.0 \%)\end{array}$ & $\begin{array}{c}7 \\
(3.3 \%)\end{array}$ & $\begin{array}{c}42 \\
(20.0 \%)\end{array}$ & $\begin{array}{c}70 \\
(33.3 \%)\end{array}$ & $\begin{array}{c}91 \\
(43.3 \%)\end{array}$ & 4.17 & 0.86 \\
\hline 13 & $\begin{array}{l}\text { I usually stay } \\
\text { awake a whole } \\
\text { night to complete } \\
\text { reading an English } \\
\text { novel. }\end{array}$ & $\begin{array}{c}42 \\
(20.0 \%)\end{array}$ & $\begin{array}{c}91 \\
(43.3 \%)\end{array}$ & $\begin{array}{c}21 \\
(10.0 \%)\end{array}$ & $\begin{array}{c}21 \\
(10.0 \%)\end{array}$ & $\begin{array}{c}35 \\
(16.7 \%)\end{array}$ & 2.60 & 1.36 \\
\hline 14 & $\begin{array}{l}\text { I have been called } \\
\text { a bookworm. }\end{array}$ & $\begin{array}{c}21 \\
(10.0 \%)\end{array}$ & $\begin{array}{c}105 \\
(50.0 \%)\end{array}$ & $\begin{array}{c}7 \\
(3.3 \%)\end{array}$ & $\begin{array}{c}42 \\
(20.0 \%)\end{array}$ & $\begin{array}{c}35 \\
(16.7 \%)\end{array}$ & 2.83 & 1.32 \\
\hline 15 & $\begin{array}{l}\text { Reading helps me } \\
\text { to relieve stress. }\end{array}$ & $\begin{array}{c}0 \\
(0.0 \%)\end{array}$ & $\begin{array}{c}14 \\
(6.7 \%)\end{array}$ & $\begin{array}{c}28 \\
(3.3 \%)\end{array}$ & $\begin{array}{c}126 \\
(60.0 \%)\end{array}$ & $\begin{array}{c}42 \\
(20.0 \%)\end{array}$ & 3.93 & 0.77 \\
\hline 16 & $\begin{array}{l}\text { Reading makes me } \\
\text { forget } \\
\text { problems }\end{array}$ & $\begin{array}{c}0 \\
(0.0 \%)\end{array}$ & $\begin{array}{c}21 \\
(10.0 \%)\end{array}$ & $\begin{array}{c}35 \\
(16.7 \%)\end{array}$ & $\begin{array}{c}98 \\
(46.7 \%)\end{array}$ & $\begin{array}{c}56 \\
(26.7 \%)\end{array}$ & 3.90 & 0.91 \\
\hline 17 & $\begin{array}{l}\text { When I read, I live } \\
\text { as a character in } \\
\text { the text I'm } \\
\text { reading. }\end{array}$ & $\begin{array}{c}7 \\
(3.3 \%)\end{array}$ & $\begin{array}{c}56 \\
(26.7 \%)\end{array}$ & $\begin{array}{c}35 \\
(16.7 \%)\end{array}$ & $\begin{array}{c}70 \\
(33.3 \%)\end{array}$ & $\begin{array}{c}42 \\
(20.0 \%)\end{array}$ & 3.40 & 1.17 \\
\hline \multirow[t]{2}{*}{18} & $\begin{array}{l}\text { I prefer reading to } \\
\text { other } \quad \text { social } \\
\text { activities. }\end{array}$ & $\begin{array}{c}14 \\
(6.7 \%)\end{array}$ & $\begin{array}{c}49 \\
(23.3 \%)\end{array}$ & $\begin{array}{c}63 \\
(30.0 \%)\end{array}$ & $\begin{array}{c}49 \\
(23.3 \%)\end{array}$ & $\begin{array}{c}35 \\
(16.7 \%)\end{array}$ & 3.20 & 1.17 \\
\hline & Average & & & & & & 3.29 & .07 \\
\hline
\end{tabular}


As shown in Table 4, the respondents reacted positively to only 8 out of 18 items which are related to positive reading habits. The highest mean score is for ninth item (Mean 4.20, SD 0.75) to which the respondents agreed that they use their smartphones to read English materials more than any other functions. For this item, 168 respondents agreed $(80.0 \%)$ while the remaining $42(20.0 \%)$ maintained a neutral stance.

The second highest mean score is for item 15 (Mean 3.93, SD 0.77) which asks the respondents if reading helps them to relieve stress. 168 respondents $(80.0 \%)$ concurred with that statement while 28 of them $(3.3 \%)$ were unsure. On the other hand, 14 respondents $(6.7 \%)$ disagreed.

At the third place are mean scores 3.90 for 2 items; items 11 (Mean 3.90, SD 1.22) and 16 (Mean 3.90, SD 0.91). Item 11 asks the respondents if they have more than 50 reading materials at home. 35 respondents (16.7\%) disagreed while 154 (73.3\%) agreed. 21 (10.0\%) maintained a neutral position.

Next, item 16 finds out if reading helps the respondents to forget their problems. 21 respondents $(10.0 \%)$ disagreed while 35 (16.7\%) of them were unsure. However, a whopping $73.4 \%$ (154) affirmed the reading does help them to forget their problems.

The lowest mean score is for item 6 (Mean 1.97, SD 0.75) which asks the respondents if they go to the library to read and borrow books every week. Most of them $(168,80.0 \%)$ disagreed with the statement whereas only $7(3.3 \%)$ agreed. 35 respondents $(16.7 \%)$ were unsure about it.

The second lowest mean score is for item 7 (Mean 2.40, SD 1.09) and item 10 (Mean 2.40, SD 1.17). The former questions the respondents if they subscribe to English language magazines. More than half $(133,63.3 \%)$ disagreed while $42(20.0 \%)$ agreed. 35 respondents $(16.7 \%)$ were neutral.

For item 10 (Mean 2.40, SD 1.17), more than half (132, 63.3\%) stated that they do not always buy English reading material online. 35 (16.7\%) were unsure and $42(20.0 \%)$ respondents stated that they do buy English reading materials online.

To surmise, the average mean score is 3.29 , which is interpreted as average value.

The subsequent analysis is of the responses to questionnaire items which are related to the negative reading habits. Table 5 exhibits the data distribution.

Table 5: Respondents' Responses to Items Related to Negative Reading Habits

\begin{tabular}{|c|c|c|c|c|c|c|c|c|}
\hline Num & Item & SD & D & $\mathbf{N}$ & $\mathbf{A}$ & $\mathbf{S A}$ & $\mathbf{M}$ & SD \\
\hline 1 & $\begin{array}{l}\text { I read English } \\
\text { materials only } \\
\text { during school } \\
\text { holidays. }\end{array}$ & $\begin{array}{c}42 \\
(20.0 \%)\end{array}$ & $\begin{array}{c}98 \\
(46.7 \%)\end{array}$ & $\begin{array}{c}28 \\
(13.3 \%)\end{array}$ & $\begin{array}{c}42 \\
(20.0 \%)\end{array}$ & $\begin{array}{c}0 \\
(0.0 \%)\end{array}$ & 2.33 & 1.01 \\
\hline 2 & $\begin{array}{l}\text { I read English } \\
\text { materials only } \\
\text { on } \\
\text { weekends. }\end{array}$ & $\begin{array}{c}42 \\
(20.0 \%)\end{array}$ & $\begin{array}{c}105 \\
(50.0)\end{array}$ & $\begin{array}{c}21 \\
(10.0 \%)\end{array}$ & $\begin{array}{c}42 \\
(20.0 \%)\end{array}$ & $\begin{array}{c}0 \\
(0.0 \%)\end{array}$ & 2.30 & 1.01 \\
\hline
\end{tabular}




\begin{tabular}{|c|c|c|c|c|c|c|c|c|c|}
\hline 3 & 3 & $\begin{array}{l}\text { I read English } \\
\text { materials for } \\
\text { less than one } \\
\text { hour a day. }\end{array}$ & $\begin{array}{c}14 \\
(6.7 \%)\end{array}$ & $\begin{array}{c}119 \\
(56.7 \%)\end{array}$ & $\begin{array}{c}21 \\
(10.0)\end{array}$ & $\begin{array}{c}49 \\
(23.3 \%)\end{array}$ & $\begin{array}{c}7 \\
(3.3 \%)\end{array}$ & 2.60 & 1.02 \\
\hline 4 & & $\begin{array}{l}\text { I go to the } \\
\text { library to read } \\
\text { or borrow books } \\
\text { every month. }\end{array}$ & $\begin{array}{c}42 \\
(20.0 \%)\end{array}$ & $\begin{array}{c}91 \\
(43.3 \%)\end{array}$ & $\begin{array}{c}21 \\
(10.0 \%)\end{array}$ & $\begin{array}{c}56 \\
(26.7 \%)\end{array}$ & $\begin{array}{c}0 \\
(0.0 \%)\end{array}$ & 2.43 & 1.09 \\
\hline 5 & & $\begin{array}{l}\text { I rarely go to the } \\
\text { library to read } \\
\text { and borrow } \\
\text { books. }\end{array}$ & $\begin{array}{c}42 \\
(20.0 \%)\end{array}$ & $\begin{array}{c}35 \\
(16.7 \%)\end{array}$ & $\begin{array}{c}28 \\
(13.3 \%)\end{array}$ & $\begin{array}{c}91 \\
(43.3 \%)\end{array}$ & $\begin{array}{c}14 \\
(6.7 \%)\end{array}$ & 3.00 & 1.29 \\
\hline 6 & 6 & $\begin{array}{l}\text { I have less than } \\
50 \text { English } \\
\text { reading } \\
\text { materials at } \\
\text { home. }\end{array}$ & $\begin{array}{c}63 \\
(30.0 \%)\end{array}$ & $\begin{array}{c}63 \\
(30.0 \%)\end{array}$ & $\begin{array}{c}28 \\
(13.3 \%)\end{array}$ & $\begin{array}{c}42 \\
(20.0 \%)\end{array}$ & $\begin{array}{c}14 \\
(6.7 \%)\end{array}$ & 2.43 & 1.29 \\
\hline & 77 & $\begin{array}{l}\text { I do not have } \\
\text { any English } \\
\text { reading material } \\
\text { at home. }\end{array}$ & $\begin{array}{c}154 \\
(73.3 \%)\end{array}$ & $\begin{array}{c}49 \\
(23.3 \%)\end{array}$ & $\begin{array}{c}7 \\
(3.3 \%)\end{array}$ & $\begin{array}{c}0 \\
(0.0 \%)\end{array}$ & $\begin{array}{c}0 \\
(0.0 \%)\end{array}$ & 1.30 & 0.53 \\
\hline 8 & 8 & $\begin{array}{l}\text { I feel bored and } \\
\text { restless when I } \\
\text { have to read } \\
\text { English } \\
\text { materials. }\end{array}$ & $\begin{array}{c}77 \\
(36.7 \%)\end{array}$ & $\begin{array}{c}91 \\
(43.3 \%)\end{array}$ & $\begin{array}{c}35 \\
(16.7 \%)\end{array}$ & $\begin{array}{c}7 \\
(3.3 \%)\end{array}$ & $\begin{array}{c}0 \\
(0.0 \%)\end{array}$ & 1.87 & 0.81 \\
\hline 9 & & $\begin{array}{l}\text { I am able to } \\
\text { spend a day } \\
\text { without reading } \\
\text { English } \\
\text { materials. }\end{array}$ & $\begin{array}{c}35 \\
(16.7 \%)\end{array}$ & $\begin{array}{c}70 \\
(33.3 \%)\end{array}$ & $\begin{array}{c}56 \\
(26.7 \%)\end{array}$ & $\begin{array}{c}42 \\
(20.0 \%)\end{array}$ & $\begin{array}{c}7 \\
(3.3 \%)\end{array}$ & 2.60 & 1.09 \\
\hline
\end{tabular}

As illustrated in Table 4, the highest mean score is for item 5 (Mean 3.0, SD 1.29) which asks if the respondents rarely go to the library to read and borrow books. 77 respondents $(36.7 \%)$ disagreed with that statement while exactly half of them $(105,50.0 \%)$ agreed. 28 respondents or $13.3 \%$ were unsure.

The second-highest mean score is for item 3 (Mean 2.60, SD 1.02) and item 9 (Mean 2.60, SD 1.09). The former is about ESL teachers spending less than an hour to read English materials, to which more than half $(133,63.4 \%)$ of the respondents disagreed. A smaller number agreed $(56,26.6 \%)$ whereas $21(10.0 \%)$ were neutral.

Item 9 is associated with the ability of the respondents to spend a day without reading any English materials. Exactly half of the respondents $(105,50.0 \%)$ disagreed with that statement. On the contrary, almost a quarter $(49,23.3 \%)$ agreed while more than quarter $(56,26.7 \%)$ stayed neutral. 
The lowest mean score is for item 7, which enquires the respondents if they do not have any English reading materials at home. Almost all of them $(203,96.6 \%)$ disagreed with $7(3.3 \%)$ staying on the fence.

In summary, the average mean score for the items related to negative reading habits is low, at $\mathrm{M}=2.32$.

\section{Discussion}

Regarding the types of English reading materials read by ESL teachers, it can be observed that the three most popular reading materials among ESL teachers are online reading materials such as social media posts $(175,83.3)$, websites $(161,76.7)$ and blogs $(14,6.6)$.

This differs with the outcome of a research done by Tharumaraj and Nordin (2011) where the top three preferred reading materials among the 65 respondents are newspaper $(19.1 \%)$, magazines $(15.2 \%)$ and websites $(14.6 \%)$. As can be seen, there is a difference in the category of materials read between this research and Tharumaraj and Noordin (2011). The preferred materials in the former are all online or digital materials whereas in the latter, most of the materials of choice are print materials.

The possible explanation for this scenario is the nine-year gap between both researches. That time frame has seen the widespread use of smartphones in everyday lives of Malaysians. This has led to online reading materials being readily accessible to every section of the society. In addition, the advent of social media apps such as Facebook, Twitter and Whatsapp have created a new lifestyle, influenced the type of content read and replaced books as popular reading materials (Adu-Sarkodee, Asante \& Akussah, 2015; Obaidullah \& Rahman, 2018).

Yet, there is a similarity between both the researches; the three most favoured materials by ESL teachers are all light materials. This research uncovers the fact that heavy reading materials such as novels $(14,6.7 \%)$, short stories $(28,13.3 \%)$ and non-fiction books $(7,3.3 \%)$ are read daily only by a minority of the teachers

Likewise, the findings of research by Tharumaraj and Nordin (2011) also show that heavy reading materials like novels $(10.5 \%)$ and fiction $(8.2 \%)$ are not very popular among EL teachers. The case is also same with non-fiction materials which are only read by $6 \%$ of the respondents.

All these only confirm the assumption that most of Malaysian EL teachers read only light materials which may not be intellectually-taxing or require a lot of their attention (Gan, 2002). It is also possible that these teachers favour light reading materials such as social media posts or newspapers to obtain information or be updated with the latest issues.

This should not be the case with EL teachers who, being role models of a society, ought to take the initiative to set a good example for the general Malaysian population. Therefore, it is high time for Malaysian EL teachers to choose more intellectually- and linguistically-demanding English reading materials instead of being limited to social media posts which are not effective in enhancing their quality as EL teachers.

In connection to this, several scholars (Liu, 2005; Lee and Wong, 2017; Kovač and van der Weel, 2018) have argued that reading social media posts does not constitute as extensive reading. 
Liu (2005), while studying digital reading of adults aged between 30 and 45 years old, point out that 'screen-based reading' involves more "browsing and scanning, keyword spotting, onetime reading, non-linear reading' as well as selective reading, and results in decreased "indepth reading, concentrated reading" and sustained attention.

Lee and Wong (2017), in their study of reading habits of Malaysian university students, point out that surfing the net or reading social media posts may not be considered as 'deep reading' due to the various distractions in the form of advertisements and multiple apps being used at the same time. These distractions are known as 'clickbaits' which disrupt the process of continuous reading with abrupt popping of links and headlines which pull readers' attention away from the online text they are reading (Lee \& Wong, 2017).

Kovač and van der Weel (2018), in their paper about 'Reading in a post-textual era', pointed out that reading texts generated on social media is not thought as extensive reading as the internet is a 'fast-paced medium', which leads to readers preferring shorter texts. They further argued that shorter texts are inherently non-complex and do not contain a wide range of vocabulary. As a result, readers, being very used to short and simple texts, develops an aversion towards longer and more complex texts.

Consequently, readers with tendencies to read short texts and eschew long-form texts may be unable to comprehend more complex ideas and linguistic structures. These readers may also lose an exposure to a wide range of vocabulary, which may not be found in social media posts in general (Kovač \& van der Weel, 2018).

In line with this, we have to accept that reading on social media should not be categorised as extensive reading and, in fact, it has been acknowledged by various studies that social media usage, especially among the younger generation, has led to the decline of reading as a leisure activity among the youth today (Adu - Sarkodee, Asante \& Akussah, 2015; Kovač \& van der Weel, 2018).

In summary, the types of reading materials read by Malaysian ESL teachers belong to the category of light material. It is also safe to conclude that online reading materials seem to have gained more popularity than print reading materials.

In terms of the rate of extensive reading among ESL teachers, analyses of the items related to positive and negative reading habits are carried out. The conclusion derived is that the rate of extensive reading among Malaysian EL teachers is average to moderately high.

In connection to items related to positive reading habit (Mean 3.29, SD 1.07), the rates of extensive reading among the respondents is considered as average. The analysis of the items show that 10 items have scored a high mean (>3.50) while 4 items have scored an average $(3.50>$ mean $>2.70)$ and low means $(<2.70)$ respectively.

Therefore, it can be concluded that Malaysian ESL teachers strongly agree that they always read English materials for more than one hour a day and while waiting. They also usually read English materials before going to bed and it is also proven that they use their smartphones to read English materials more than other functions.

The analysis further shows that ESL teachers in Malaysia possess more than 50 reading materials at home. Furthermore, it can be agreed that they definitely feel relaxed when they 
read English materials and reading helps them to relieve stress. Correspondingly, ESL teachers strongly believe that reading is a form of escapism as it helps them to forget their problems.

Next, the respondents also moderately agree that they read English reading materials when having meals alone and while travelling. They also agree that, at an average degree, they always buy English reading materials from the bookstores and that their strong reading habits have resulted in them being called a 'book-worm'. Moreover, they moderately agree that when they read, they live as the character in the text they are reading. Finally, the respondents fairly concur that they prefer reading to other social activities.

On the contrary, the respondents do admit that they do not go to the library to read and borrow books every week nor do they subscribe to any English language magazines. Furthermore, it can be seen that purchasing reading materials online is not as widespread among ESL teachers as it should be. Also, the fact that more than half of the respondents acknowledge that they do not stay awake a whole night to complete reading an English novel also show the lack of a vociferous reading habit among Malaysian ESL teachers.

However, analysis of the questionnaire items related to negative reading habits also discloses the fact that ESL teachers do not shun reading altogether. Based on the items with the three lowest mean scores, we can generalise that most of them do have English reading materials at home, do not feel bored and restless when they have to read English materials and do not read English materials only during school holidays.

Nevertheless, it is worrying to see that the respondents' reading habits are not strong enough to fulfil the criteria of extensive and enthusiastic readers. This is based on the above-mentioned analysis which presents the fact that the respondents agree that they rarely go to the library to read and borrow books, read English materials for less than one hour a day and are able to spend a day without reading any English materials.

The analysis of types of reading materials preferred by the respondents also depicts a serious disinterest and indifference towards heavier and more demanding reading material such as novels, short stories and non-fiction books. Only 28 respondents or $13.4 \%$ of the respondents read novels at least 5 days in a week whereas merely $23.3 \%$ read short stories as frequently.

In contrast, a whopping 50\% do not read novels at any time in a week while nearly half at $40 \%$ do not read short stories at all. This trend continues with non-fiction books and encyclopaedia which are not read by $50 \%$ of the respondents in a week.

Overall, it is clear to see that while the data analysis exhibits an average to moderately high reading frequency among Malaysian ESL teachers, the types of reading materials read by them should also be taken into consideration. There is a consensus among reading experts that extensive reading should involve heavier and more demanding materials like novels or short stories rather than social media posts, websites or newspapers.

This finding conforms to the one by Tharumaraj and Noordin (2011) who found that ESL teachers in Malaysia 'do read' but not extensively and certainly not as much as "watching television or movies." The ones who did read stated that they chose their materials which had "interesting titles and topics" as well as ones which help increase their knowledge and develop language skills. 
Tharumaraj and Noordin's findings are similar to the findings of a research by Giles and Tunks (2019) who uncovered an inclination towards aliteracy among 24 teachers who are enrolled as graduate students in a south-eastern American university. Even here, the respondents admit that watching movies is the most preferred leisure-type activities as compared to reading literature for pleasure, which is ranked at $8^{\text {th }}$ spot.

A study by Nathanson, Pruslow and Levitt (2008) also illustrated the growing problem of aliteracy among 788 inservice and prospective literacy and special education teachers in New York. The findings show less than half of the respondents that is only $47 \%$ identified themselves as "enthusiastic to highly enthusiastic readers" while $17 \%$ admitted that they did not find reading enjoyable. The rest of the respondents indicated that they only read "if and when they had time". On the whole, the researchers discovered that reading is not viewed with strong passion and enthusiasm by these teachers.

Going by the discussion above, it is safe to summarise that the rates of reading among ESL teachers in Malaysia is at an average to moderately high level, albeit the fact that only light materials are mostly read.

\section{Summary}

It is highly necessary for actions to be taken to promote a more extensive reading habit among EL teachers in Malaysia. By that, the burden to do so should not fall squarely on the teachers but also on all the policy makers and enforcers of the Malaysian education system.

First and foremost, the Ministry of Education has to take the steps to ensure that EL teachers' workloads are reduced so that the freed-up time can be used for leisure reading. This can be done by hiring teacher assistants, a long overdue proposal, who would take over non-teaching duties from teachers. With more time in hand and less exhaustion, it is more likely for EL teachers to read more challenging materials extensively.

Secondly, reading programmes for teachers should be carried out during working hours instead of out. Currently, teachers are required to key in online about the reading materials read in a year which may result in data inaccuracy. Teachers may key in due to pressure from the school administrators who would pester them for the data, so that their scores would meet their demands.

In comparison, an in-house reading programme would be more efficient in encouraging EL teachers to read. The ministry could implement nationwide reading programmes, such as Drop Everything and Read (DEAR) or Silent Sustained Reading (SSR) for EL teachers to read during working hours.

\section{Reference}

Adebayo, O. (2009). Reading habits of secondary school teachers: A study of selected secondary schools in Ado-Odo Ota local government area. Library Philosophy and Practice (e-journal).290. Retrieved from http://digitalcommons.unl.edu/cgi/viewcontent. cgi? article= 1293\&context=libphilprac

Adu-Sarkodee, R., Asante, E. \& Akussah, M. (2015). Relationship between Uses of Social Media in Reading Habits: Evidence from Senior High Students in Ghana. Information and Knowledge Management, Vol.5, No.11, 2015. Retrieved from https://www.iiste.org/Journals/index.php/IKM/article/download/26981/27664 
Ak çay, A. (2017). A Research on Book Reading Habits of Turkish Teachers. Journal of Education and Training Studies. Vol.5, No.10; October 2017. Retrieved from http://redfame.com/journal/index.php/jets/article/view/2609/2784

Applegate, A.J. \& Applegate, M.D. (2004). The Peter Effect: Reading habits and attitudes of presevice teachers. The Reading Teacher, 57(6). March 2004. Retrieved from https://thoughtfulliteracy.com/Applegate\% $\% 202004 \% 20$ The\%20 Peter\%20Effect.pdf

20and\%20Applegate,

Cabaran masa kini tugas dan tanggungjawab seorang guru (2016, April 14). MYNEWSHUB. Retrieved on $18^{\text {th }}$ April 2018 from https://www.mynewshub.cc/terkini/cabaran-masakini-tugas-dan-tanggungjawab-seorang-guru/

Daik, S. (2006). Reading habits of teachers in four government-aided secondary schools (Mission schools) in Kuching district (Masters Project Paper). Universiti Teknologi Malaysia, Johor, Malaysia. Retrieved from https://www.scribd.com/document/30886055/Borang-Pengesahan-Status-Tesis-Utm

Donaldson, T.C.F. (2013). An investigation into reading habits of Texas middle and high school English language arts teachers. (Doctoral dissertation, Texas A\&M UniversityCorpus Christi, Texas, United States of America). Retrieved from https://tamuccir.tdl.org/tamuccir/bitstream/handle/1969.6/504/Dissertation\%20Tammy\%20Cene\%2 0 Francis\%20Donaldson .pdf?sequence $=1$

Giles, R.M. \& Tunks, K.W. (2019). Aliteracy Among Teachers? Investigating the Reading Habits of Elementary and Early Childhood Educators. Journal of Contemporary Educational Research. Volume 3, Issue 3. Retrieved from http://www.bbwpublisher.com/index.php/JCER/article/view/384

Hassen, R. (2016). Reading habits of secondary school teachers: A study of selected secondary schools in Addis Ababa and Dessie. Journal of Education and Practice. 7(22). Retrieved from http://files.eric.ed.gov/fulltext/EJ1112948.pdf

Inderjit, S. (2014). Reading trends and improving reading skills among students in Malaysia. International Journal of Research in Social Sciences, 3(5), 70 - 81. Retrieved from http://www.ijsk.org/uploads/3/1/1/7/3117743/6_reading_skills.pdf

Kovač, M. \& van der Weel, A. (2018). Reading in a post-textual era. first Monday. Volume 23, $\begin{array}{lllllll}\text { Number } & 10 & - & 1 & \text { October } & 2018 . & \text { Retrieved from }\end{array}$ https://firstmonday.org/ojs/index.php/fm/article/view/9416/7592

Kwek, D., Albright, J. \& Kramer-Dahl, A. (2007). Building teachers' creative capabilities in Singapore's English classroom: a way of contesting pedagogical instrumentality. Literacy. Volume 41, Number 2, July 2007. Retrieved from https://onlinelibrary.wiley.com/doi/abs/10.1111/j.1467-9345.2007.00460.x

Liu, Z. (2005). Reading behaviour in the digital environment: Changes in reading behaviour over the past ten years. Journal of Documentation. Vol. 61 No.6, 2005, pp. $700-712$. Retrieved from https://pdfs.semanticscholar.org/2dfd/8e98a271cc7d92bde32d216f2 54c8800e205.pdf

Napsiah Kepol (2017). Quality Malaysian English language teachers: Examining a policy strategy. Malaysian Journal of Learning and Instruction. 4(1), 187-209. Retrieved from https://files.eric.ed.gov/fulltext/EJ1150438.pdf

Nathanson, S., Pruslow, J. \& Levitt, R. The Reading Habits and Literacy Attitudes of Inservice and Prospective Teachers. Journal of Teacher Education. Volume 59, Number 4, September/October 2008313 - 321. Sage Publications. Retrieved from https://journalssagepub-com.ezproxy.um.edu.my/doi/pdf/10.1177/0022487108321685

Pandian, A. (1997). Reading in Malaysia. Bangi: Penerbit Universiti Kebangsaan Malaysia. 
Richards, J.C. \& Schmidt, R. (2002). Longman Dictionary of Language Teaching \& Applied Linguistics. London: Pearson Education

Tharumaraj, J.N. \& Noordin, N. (2011). Analysing Teachers' Reading Habits and Teaching Strategies For Reading Skills. Malaysian Journal of ELT Research. ISSN: 1511 - 8002, Vol. 7(1), 2011. Retrieved from https://journals.melta.org.my/index.php/majer/article/view/176/89 